\title{
Extensive scrotal calcinosis
}

\author{
Fabrizio Schonauer • Guido Molea
}

Received: 21 October 2009 /Accepted: 12 November 2009 /Published online: 4 December 2009

(C) Springer-Verlag 2009

Sir,

We just read the case report entitled" Extensive scrotal calcinosis" by Demirdover et al. [1] and would like to share with the authors and the Journal's readers our clinical experience on the subject.

Scrotal calcinosis is a rare condition usually found in young male patients [2-4].

Fig. 1 Case 1: extensive scrotal calcinosis

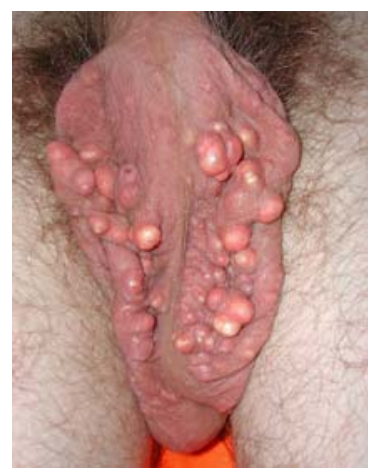

Fig. 2 Case 1: preplanning with $\mathrm{W}$ plasty design

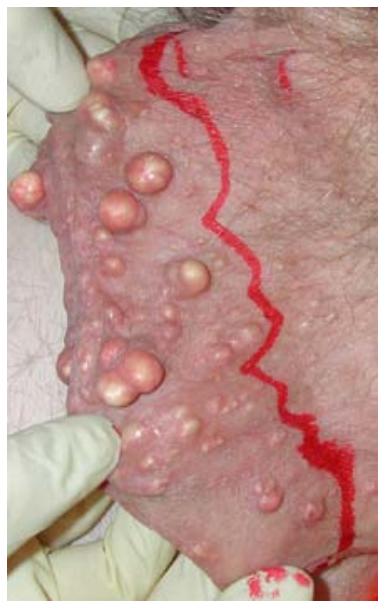

F. Schonauer $\cdot$ G. Molea $(\bowtie)$

University of Naples "Federico II",

Naples, Italy

e-mail: molea@unina.it
Fig. 3 Case 1: defect direct closure

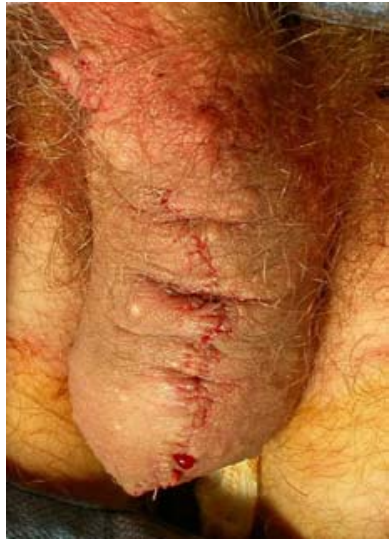

We have treated three patients in the last 5 years for scrotal calcinosis; age range, 19-42. The technique we used was very similar to that described by Demirdover et al. consisting in excision of the affected scrotal tissue and direct closure $[1,5]$. We have found it useful to pre-plan the extensive scrotal skin excision (Fig. 1) with a W plasty design (Fig. 2) to interrupt the final scar (Fig. 3). Our three patients healed uneventfully.

In case of a recurrence, which we did not have, we would probably advise defect reconstruction with skin grafts.

\section{References}

1. Demirdover C, Ozkan HS, Sahin B (2009) Extensive scrotal calcinosis. Eur J Plast Surg (in press)

2. Akosa AB, Gilliland EA, Ali MH, Khoo CT (1989) Idiopathic scrotal calcinosis: a possible aetiology reaffirmed. Br J Plast Surg 42(3):324-327

3. Demir Y, Latifoğlu O, Yenidünya S, Celebi C (2000) Idiopathic calcinosis of the scrotum. Ann Plast Surg 45(2):223-224

4. Gi N, Gupta AK, Sachi K, Thomas S (2008) Idiopathic scrotal calcinosis - a pedunculated rare variant. J Plast Reconstr Aesthet Surg 61(4):466-467

5. Theuvenet WJ, Nolthenius-Puylaert T, Giedrojc Juraha ZL, Borghouts JM, van Twisk R (1984) Massive deformation of the scrotal wall by idiopathic calcinosis of the scrotum. Plast Reconstr Surg 74(4):539-543 